\title{
日本と韓国の情報通信
}

\section{製造部門の実質化と 部門間波及効果}

\section{5-2000-2005-2008 年接続産業連関表を用いて}

明素延

1990 年代後半からの情報通信技術の急速な発展に伴い半導体 などの情報通信機器の価格低下が著しく, 経済全体における情 報通信機器の活用による生産性向上の効果が注目されている. 本稿では, 日本と韓国の ICT 製造部門において固定基準年方 式による既存の接続産業連関表のデフレーター及び実質値のバ イアス可能性を検討したうえで, ICT 製造部門の生産性向上 が他産業部門の生産性に与える効果の計測を行った. 分析の結 果, 情報通信機器の価格低下が既存の接続産業連関表のデフレ 一ターに充分に反映されていないことが明らかになった。 そし て, このような情報通信機器の価格低下の過少評価は韓国の方 が大きく, ICT 製造部門の生産性向上による他産業部門への コスト削減効果あるいは生産性向上に与える効果が過小または 過大評価になっていることがわかった。

\section{1. はじめに}

1990 年代後半からの情報通信技術（Information Communication Technology: $\mathrm{ICT}^{1)}$ ) の 急速な発展に伴いコンピューターや半導体など の情報通信機器の質の上昇と共に価格低下が著 しく，経済全体における情報通信機器の活用が 世界的に拡大している。このような情報通信機 器の技術進歩及びそれによってもたらされる質 の上昇を伴う価格低下により，より少ない生産
要素投入（コスト）で生産が可能になるため, 情報通信機器を活用するそれぞれの各産業及び 経済全体の生産性向上に大きな影響を及ぼして いる，特に，少子高齢化が本格化する日本と韓 国では，生産性の向上が経済成長の鍵となって おり，情報通信機器の活用はマクロ・レベルの 生産性向上を通して, 日本と韓国の経済に重大 な影響を与えているといえる。

このように一国の経済全体のマクロ分析や他 産業部門への影響などを時系列でみる経済分析 にもっとも有効なデータを提供する統計資料と 
して，接続産業連関表が挙げられる。韓国と日 本の接続産業連関表は, 比較時点の数量をウエ イトとする固定基準年方式のパーシェ型デフレ ーターを用いて実質值を作成している。しかし ながら，固定基準年方式によるデフレーターを 用いて実質化される既存の接続産業連関表は, 近年の技術革新による質の上昇を伴う価格低下 や経済構造の変化が著しい実態経済の状況が十 分に反映されていないため, 実質化された産業 連関表はバイアスをもたらす可能性があると考 えられる。特に, 情報通信製造部門（以下 ICT 製造部門）は技術進歩による質の上昇を 伴う価格低下は著しく, 価格低下の速度が他の 産業と比較して速い. また, 数量も急速に上昇 してきている．このように，価格変化や数量変 化が大きい部門に対して固定基準年方式による デフレーターは大きくバイアスが生じることに なる。また，基準年が比較時点から 5 年以上離 れているため, 基準時点から離れるほどそのバ イアスはさらに大きくなる．このような固定基 準年方式のバイアスを取り除く一つの方法は, 価格及び数量が急速に変化した場合でも正確に 測定が出来るフィッシャー型のデフレーターを 作成することである。

このような, 産業連関分析の際に ICT 製造 部門のデフレーターのバイアス問題を考慮して 情報通信機器の生産性向上が中間投入を通じて 他産業部門の生産性に与える効果を検討した先 行研究は筆者の知る限りみられないが, 情報通 信機器の活用がマクロ的な経済成長にどのよう な影響を与えるのかについては様々な研究が行 われている。まず，情報通信部門を対象に産業 構造の変化や経済への影響分析についての最近 の産業連関表を用いた日本と韓国の研究には, キム・ジョンウン他 (2010), 篠崎・山本 （2010）などがある。そして，IT 資本蓄積によ る生産性向上効果の研究には, Jorgenson and $\mathrm{Vu}$ (2005)，シン (2008) などがある。これら の研究では, IT 部門そのものの生産性上昇は 他部門の生産性上昇より大きく, IT 資本蓄積 によるマクロ全体の生産性を引き上げる効果が
あると述べられている。ただし，韓国経済は IT 部門以外の IT 活用は低く,このことが産 業間の生産性格差が生じた原因のひとつである と指摘されており, 韓国と日本のサービス産業 の生産性は IT 活用が低いことが原因でアメリ カと比べて低いと述べられている。

しかしながら，これら先行研究では，いわゆ る「ICT 革命」による情報通信機器の普及が 他の産業部門の生産性を引き上げたかどうかに ついては明らかにされていない.

そこで本稿では, 日本と韓国の ICT 製造部 門2)の技術進歩による価格低下が固定基準年方 式による既存の接続産業連関表のデフレーター に充分に反映されているかを確かめたうえで, ICT 製造部門の生産性向上が，産業間の相互 依存関係を通じて他産業部門の生産性に与える 効果の計測を行うことを目的とする。

本稿の特徵としては, 以下の点があげられ る.

第 1 に, 日本と韓国を対象に基本分類の最新 の産業連関表を用いて価格基準を 2005 年価格 で統一した 1995-2000-2005-2008 年接続産業連 関表を作成し，日本と韓国の共通分類の 67 部 門に集計を行うことである。

第 2 に, 価格低下が著しく, 数量変化も大き い ICT 製造部門に対してフィッシャー型のデ フレーターを作成し実質化を試みる。その際 に，日本の 10 桁品目と韓国の 7 桁品目による それぞれの品目別の物価指数及び国内生産額の 作成・推計を行い，産業連関表の基本分類にお けるデフレーターを作成する。次に，フィッシ ヤー型のデフレーターによる実質化を行い, 公 表された既存の産業連関表の実質值との比較を 行うことである。

第 3 に, 産業連関分析の価格モデルを応用し て, ICT 製造部門の生産性向上が他産業部門 に及ぼすコスト削減効果あるいは生産性に与え る効果のシミュレーションを行う。白の際, 成 長部門として注目されているサービス部門を 4 ブロックに集計し，全部門を 11 ブロック別に 再配列を行うことである。 
以下ではまず第 2 節で，韓国と日本における ICT 製造部門に対してフィッシャー型のデフ レーターを作成し実質化を試みる。第 3 節では ICT 製造部門においてフィッシャー型デフレ ーターを用いて作成した接続産業連関表による ICT 製造部門の生産性向上が，他産業部門の 生産性に与える効果のシミュレーションを行い 既存の接続産業連関表による効果との比較を行 う。そして，最後の第 4 節では，本稿のまとめ を行う。

\section{ICT 製造部門の国内生産品デ フレーター作成及び実質化}

\section{2-1 デー夕作成}

固定基準年方式による接続産業連関表のデフ レーター及び実質值のバイアス問題を考慮し て，1995-2000-2005-2008 年接続産業連関表 ${ }^{3)}$ を再評価する。特に，技術進歩によってもたさ れる質の上昇を伴う価格低下が著しく, 数量変 化も大きい ICT 製造部門に対してフィッシャ 一型のデフレーターを作成し実質化を試みる。

図 1 は，1995-2000-2005-2008 年接続産業連
関表の ICT 製造部門においての物価指数方 法4)による国内生産品デフレーター作成と実質 化のながれである。

ICT 製造部門に対して, 産業連関表のもっ とも細かい品目である，日本の 10 桁，韓国の 7 桁の品目を用いて日本と韓国の基本分類にお ける国内生産品のデフレーターを作成する。物 価指数方法によるより正確なデフレーターの作 成をするには，可能な限り多くの細品目の各年 の物価指数とシェアとなる生産額が必要であ る. 国内生産品デフレーターの推計に用いられ る主な統計資料及び作成方法は次のようであ る.

\section{1 段階：品目別の物価指数及び生産額の作成}

韓国は, 品目別の物価指数は, 韓国銀行の 「生産者物価指数（2005 年基準）」用いる。公 表される生産者物価指数の 884 品目の中で産業 連関表の ICT 製造部門の 7 桁に合わせて 60 品 目の物価指数を作成する。しかし，品目変動が 頻繫な ICT 製造部門のすべての 7 桁品目につ いて 1995 年からのデー夕を得ることは出来な い. そのため, 60 品目の中で生産者物価指数 を得られない場合は，7桁の該当品目が含まれ

図 1 ICT 製造部門のデフレーター作成と実質化の手順
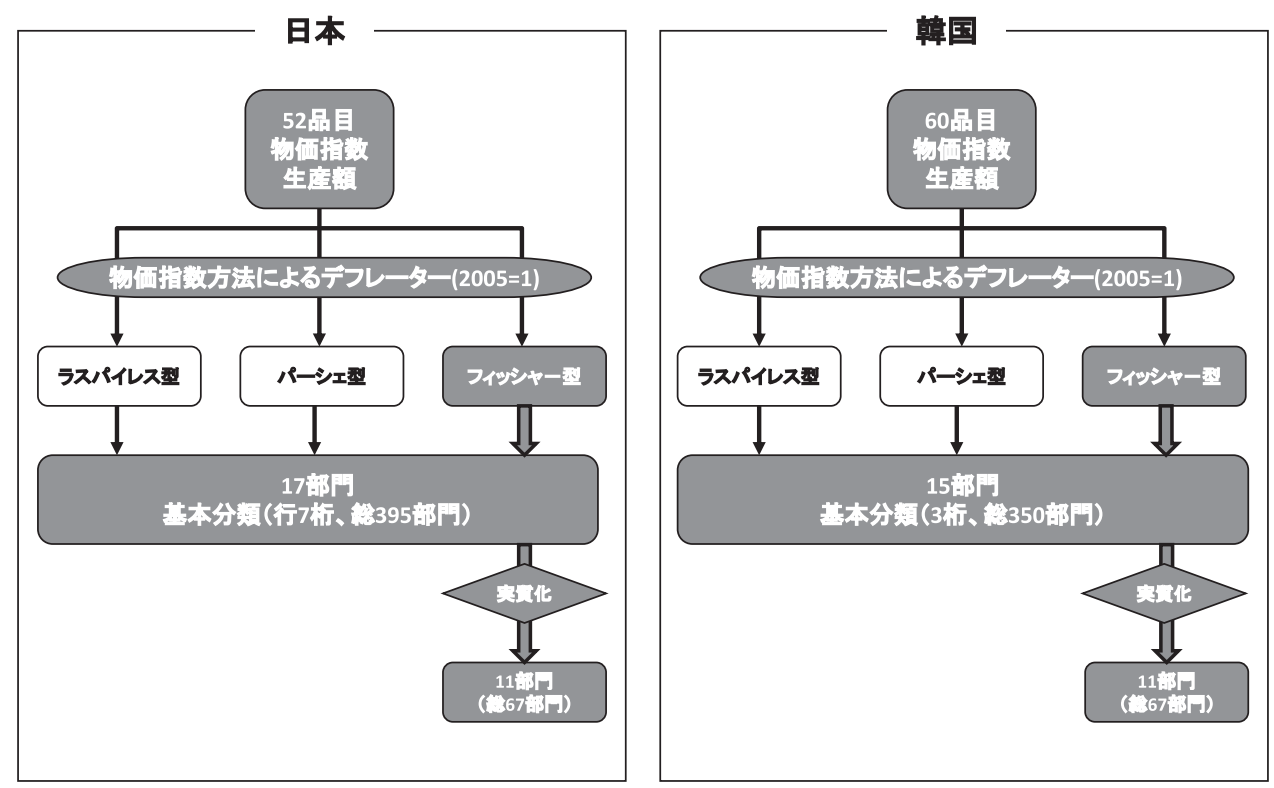
る 4 枌の基本分類の生産者物価指数のトレンド を用いて 1995 年から 2011 年までの推計を行 う。また, 求める該当品目より品目が細かい場 合は加重值をウェイトとして加重平均による生 産者物価指数を統合する。品目別の生産額は, 産業連関表の付带表「部門別品目別供給額表」 の 7 桁品目を生産額として用いる. 品目分類 は，作成した物価指数と同じ 60 品目とする。 日本と異なり，延長表である 2008 年について も産業連関表の付带表の「部門別品目別供給額 表」が公表されている。また，品目の変更や統 合によって「部門別品目別供給額表」による生 産額が不明な場合は, 統計庁の「釷工業統計調 査報告書」及び「電子・電気製造業実態調査」, 韓国電子情報通信産業振興会の「品目別需給統 計」の生産額及び生産量を用いて推計を行う。

日本は, 品目別の物価指数は, 日本銀行の 「国内企業物価指数 ${ }^{5)} 」$ を用いて産業連関表の ICT 製造部門の 10 桁に合わせて 1995 年から 2011 年までの 52 品目の物価指数を作成する. 品目別の国内企業物価指数に関しては, 基準年 ごとで定義等が異なる品目が多いため，長期間 における国内企業物価指数は得られない. その ため，それぞれ異なる基準年の物価指数に対し てリンク係数を作成して接続物価指数 ${ }^{6}$ を作成 する。そして，それぞれの基準年ことに異なる 品目の中で，接続物価指数の品目より品目の数 が多い場合は，国内企業物価指数の「品目分類 編成」から品目別のウェイトを用いて加重平均 して統合する。一方，接続物価指数の品目より 品目の数が少ない場合は, 該当品目が含まれて いる代表品目の物価指数を代替物価指数として 利用する。品目別の生産額は，産業連関表の付 帯表「部門別品目別国内生産額表」の 10 桁品 目を生産額として用いる。品目分類は，作成し た接続物価指数と同じ 52 品目とする。ただし, 延長表の 2008 年においては, 産業連関表の付 帯表である「部門別品目別国内生産額表」が存 在しないため次のように推計を行う。

製造業の国内生産額を推計する統計データと して利用できるのは，経済産業省の「生産動態
統計調査」と「工業統計調查 ${ }^{7)} 」$ がある。従っ て, 2008 年の品目別の国内生産額の推計は, まず，2005 年の「部門別品目別国内生産額表」 と「生産動態統計調査」の生産額を比較し, 該 当品目の両統計の生産額が一致する場合は, 2008 年の「生産動態統計調査」の生産額をそ のまま利用する。一方，該当品目の両統計の生 産額が一致しない場合は, 2005 年「部門別品 目別国内生産額表」を基準にして「生産動態統 計調査」の生産額の 2005 年から 2008 年までの 伸び率を用いて推計を行う。なお，「生産動態 統計調査」により生産額の推計が出来ない品 目 ${ }^{8)}$ については,「工業統計調查」6椼の品目別 の出荷金額の伸び率を利用し推計を行う。それ でも推計が出来ない品目については, 類似品 目，または，大分類の品目の推計值や過去トレ ンドを用いて推計を行う。

\section{2 段階：ICT 製造部門の基本分類の国内生産品 のデフレーター作成}

作成した品目別の物価指数と生産額を用いて 接続産業連関表の基本分類の国内生産品のデフ レーターを作成する。その際，基本分類に含ま れる複数の該当品目の生産額と物価指数を用い て物価指数方法によるラスパイレス型，パーシ エ型，フィッシャー型のデフレーターを作成す る.

日本の場合は，作成した 52 品目を産業連関 表の基本分類である 7 桁の 17 部門の ICT 製造 部門の国内生産品のデフレーターを作成する. 韓国の場合は，作成した 60 品目を産業連関表 の基本分類である 3 桁の 15 部門の ICT 製造部 門の国内生産品のデフレーターを作成する。物 価指数方法によるラスパイレス型，パーシェ 型，フィッシャー型のデフレーターを数式で表 すと次のようである。

ラスパイレス型のデフレーター $(P L D)$ は, 細品目の基準時点における国内生産額をウェイ トとして物価倍率を加重したインフレーターの 逆数である。 


$$
P L D^{t}=\frac{\sum_{i} x_{i}^{0}}{\sum_{i} \frac{p_{i}^{0}}{p_{i}^{t}} x_{i}^{0}}
$$

ただし， x と p は細品目（i）の国内生産額 と物価指数であり, 0 と $\mathrm{t}$ は基準時点と比較時 点である。

$$
\text { パーシェ型のデフレーター（PPD）は, 細 }
$$

品目の比較時点における国内生産額をウェイト として物価倍率を加重したインフレーターの逆 数である。

$$
P P D^{t}=\frac{\sum_{i} x_{i}^{t}}{\sum_{i} \frac{p_{i}^{0}}{p_{i}^{t}} x_{i}^{t}}
$$

フィッシャー型のデフレーター（PFD）は, ラスパイレス型のデフレーターとパーシェ型の デフレーターの幾何平均である。

$$
P F D^{t}=\sqrt{P L D^{t} \times P P D^{t}}
$$

3 段階：フィッシャー型のデフレーターによる

\section{実質化}

1995-2000-2005-2008 年接続産業連関表の基 本分類（日本は正方化された 395 部門，韓国は 350 部門）の中で ICT 製造部門において作成 したフィッシャー型のデフレーターを用いて該 当品目の国内生産額と内生部門の対角部分（自 部門のみ）を実質化する。基本分類の日本は 395 部門の中で 17 部門, 韓国は 350 部門の中 で 15 部門の ICT 製造部門に対して名目值をフ イッシャー型のデフレーターで除する。その 後, 両国の共通分類である 67 部門に集計を行 う。共通分類の 67 部門の中で 11 部門 ${ }^{9)}$ が ICT 製造部門である。ただし，ICT 製造部門を除 く基本部門の実質值は公表された産業連関表の 值をそのまま利用する。

\section{2-2 分析結果}

\begin{tabular}{|c|c|c|c|c|c|c|c|c|c|}
\hline \multicolumn{2}{|r|}{ 基本分類 } & \multicolumn{4}{|c|}{ 既存の産業連関表のデフレーター } & \multicolumn{4}{|c|}{ フィッシャー型デフレーター } \\
\hline コード & 部門名 & 1995 & 2000 & 2005 & 2008 & 1995 & 2000 & 2005 & 2008 \\
\hline 219 & 電子管 & 1.49 & 1.55 & 1.00 & 0.89 & 2.59 & 1.87 & 1.00 & 0.80 \\
\hline 220 & デジタル表示装置 & 5.89 & 2.81 & 1.00 & 0.88 & 5.16 & 4.13 & 1.00 & 0.63 \\
\hline 221 & 個別素子 & 1.61 & 1.44 & 1.00 & 1.18 & 2.00 & 1.70 & 1.00 & 1.03 \\
\hline 222 & 集積回路（IC） & 3.88 & 1.94 & 1.00 & 0.71 & 6.01 & 3.89 & 1.00 & 0.25 \\
\hline 223 & 抵抗器·蓄電器 & 1.53 & 1.78 & 1.00 & 1.05 & 1.50 & 1.77 & 1.00 & 0.94 \\
\hline 224 & 電子コイル·変成器 & 0.95 & 0.94 & 1.00 & 1.10 & 0.93 & 0.92 & 1.00 & 1.14 \\
\hline 225 & 印刷回路基板 & 1.48 & 1.46 & 1.00 & 0.98 & 1.79 & 1.60 & 1.00 & 0.91 \\
\hline 226 & その他の電子部品 & 1.31 & 1.26 & 1.00 & 0.87 & 1.68 & 1.71 & 1.00 & 0.95 \\
\hline 227 & テレビ & 1.50 & 1.53 & 1.00 & 0.73 & 1.87 & 1.49 & 1.00 & 0.59 \\
\hline 228 & 音響機器 & 1.13 & 1.31 & 1.00 & 0.97 & 1.52 & 1.22 & 1.00 & 0.84 \\
\hline 229 & その他映像音響機器 & 1.38 & 1.31 & 1.00 & 0.97 & 1.65 & 1.45 & 1.00 & 0.88 \\
\hline 230 & 有線通信機器 & 1.22 & 1.16 & 1.00 & 0.99 & 1.25 & 1.19 & 1.00 & 0.95 \\
\hline 231 & 無線通信機器 ·放送装備 & 2.39 & 1.82 & 1.00 & 0.95 & 6.49 & 3.64 & 1.00 & 0.62 \\
\hline 232 & コンピューター・周辺機器 & 2.66 & 1.93 & 1.00 & 0.86 & 5.04 & 3.28 & 1.00 & 0.60 \\
\hline 233 & 事務用機器 & 1.16 & 1.10 & 1.00 & 0.89 & 1.24 & 1.18 & 1.00 & 0.97 \\
\hline \multicolumn{2}{|r|}{ 基本分類 } & \multicolumn{4}{|c|}{ 既存の産業連関表の国内生産額（2005 年価格） } & \multicolumn{4}{|c|}{ 新国内生産額（2005 年価格） } \\
\hline コード & 部門名 & 1995 & 2000 & 2005 & 2008 & 1995 & 2000 & 2005 & 2008 \\
\hline 219 & 電子管 & $2,577,466$ & $4,169,224$ & $2,544,203$ & 729,848 & $1,483,058$ & $3,455,341$ & $2,544,203$ & 807,471 \\
\hline 220 & デジタル表示装置 & 24,773 & $2,730,213$ & $32,693,326$ & $56,851,771$ & 28,301 & $1,857,742$ & $32,693,326$ & $80,180,749$ \\
\hline 221 & 個別素子 & 568,541 & $1,959,220$ & $2,903,392$ & $4,439,318$ & 457,736 & $1,666,101$ & $2,903,392$ & $5,064,729$ \\
\hline 222 & 集積回路（IC） & $4,279,337$ & $16,321,614$ & $34,320,356$ & $48,425,537$ & $2,760,658$ & $8,167,586$ & $34,320,356$ & $135,686,137$ \\
\hline 223 & 抵抗器·蓄電器 & 716,228 & $1,177,437$ & $1,440,629$ & $1,532,453$ & 726,573 & $1,185,272$ & $1,440,629$ & $1,709,028$ \\
\hline 224 & 電子コイル・変成器 & 563,699 & 907,036 & 737,738 & 565,637 & 573,298 & 926,765 & 737,738 & 544,839 \\
\hline 225 & 印刷回路基板 & 921,061 & $2,570,204$ & $7,123,015$ & $8,167,139$ & 761,823 & $2,345,057$ & $7,123,015$ & $8,839,202$ \\
\hline 226 & その他の電子部品 & $1,366,893$ & $2,876,979$ & $2,805,226$ & $3,061,707$ & $1,064,075$ & $2,122,012$ & $2,805,226$ & $2,809,495$ \\
\hline 227 & テレビ & $2,715,670$ & $2,181,952$ & $5,768,863$ & $7,429,404$ & $2,174,586$ & $2,248,822$ & $5,768,863$ & $9,243,151$ \\
\hline 228 & 音響機器 & $2,149,611$ & $1,650,124$ & $2,229,099$ & $1,765,208$ & $1,595,979$ & $1,766,957$ & $2,229,099$ & $2,043,292$ \\
\hline 229 & その他映像音響機器 & $2,042,179$ & $2,420,898$ & $2,262,919$ & $1,770,224$ & $1,698,532$ & $2,196,324$ & $2,262,919$ & $1,955,228$ \\
\hline 230 & 有線通信機器 & $2,508,265$ & $4,618,882$ & $3,484,713$ & $3,615,411$ & $2,451,613$ & $4,524,410$ & $3,484,713$ & $3,762,229$ \\
\hline 231 & 無線通信機器·放送装備 & 967,533 & $9,791,525$ & $37,772,645$ & $56,872,317$ & 356,130 & $4,888,348$ & $37,772,645$ & $87,333,640$ \\
\hline 232 & コンピューター・周辺機器 & $2,624,949$ & $10,677,701$ & $9,498,135$ & $10,088,055$ & $1,386,486$ & $6,284,462$ & $9,498,135$ & $14,537,682$ \\
\hline 233 & 事務用機器 & 684,926 & $1,138,385$ & $1,408,160$ & $1,757,791$ & 641,281 & $1,062,158$ & $1,408,160$ & $1,613,686$ \\
\hline
\end{tabular}

ICT 製造部門における国内生産品のフィッ シャー型のデフレーターを作成し，該当部門に

表 1 韓国の国内生産額及び国内生産品デフレーターの比較（単位 : 百万ウォン） 
対して国内生産額の実質化した結果は，以下の ようである。

表 1 と表 2 のように産業連関表の基本分類で みると, 韓国は, ICT 製造部門の総 15 部門の 中で「220 デジタル表示装置」「223 抵抗器・蓄 電器」「224 電子コイル・変成器」の 3 部門を 除くと既存の産業連関表のデフレーターよりフ イッシャー型デフレーターの価格低下が大き い.一方，日本は，ICT 製造部門の総 17 部門 の中で「3311021 電気音響機器」「3321011 有線 電気通信機器」「3321031 無線電気通信機器 (除携带電話機)」「3331031 電子計算機付属装 置」「3421011 電子管」「3421031 磁気テープ・ 磁気ディスク」「3421099 その他の電子部品」 の 7 部門を除くと既存の産業連関表のデフレー ターよりフィッシャー型デフレーターの価格低 下が大きい。このように，既存の産業連関表の デフレーターよりフィッシャー型デフレーター
の価格低下が大きい部門においては，フィッシ ヤー型デフレーターによる実質国内生産額（以 下，新国内生産額）は，1995 年及び 2000 年は 公表された実質值より低く, 2008 年は公表さ れた実質值より大きくなる。

表 3 は，日本と韓国の共通部門の 67 部門に 集計した既存の産業連関表の実質国内生産額と 新国内生産額の変化をパーセント ${ }^{10)}$ で示した 表である，全体的にみると，韓国は既存の産業 連関表のデフレーターよりフィッシャー型デフ レーターの価格低下が大きいため全体の国内生 産額の差も大きい。新国内生産額は，既存の産 業連関表の国内生産額と比べてそれぞれ $-0.6 \%,-1.3 \%, 6.4 \%$ 増減している。一方, 日本は既存の産業連関表のデフレーターとフィ ッシャー型デフレーターの価格低下の差は大き くないため全体の国内生産額の差が韓国より少 ない。新国内生産額は，既存の産業連関表の国

表 2 日本の国内生産額及び国内生産品デフレーターの比較（単位 : 百万円）

\begin{tabular}{|c|c|c|c|c|c|c|c|c|c|}
\hline \multicolumn{2}{|r|}{ 基本分類 } & \multicolumn{4}{|c|}{ 既存の産業連関表のデフレーター } & \multicolumn{4}{|c|}{ フィッシャー型デフレーター } \\
\hline コード(行) & 部門名 & 1995 & 2000 & 2005 & 2008 & 1995 & 2000 & 2005 & 2008 \\
\hline 3111011 & 複写機 & 1.17 & 1.02 & 1.00 & 0.92 & 1.18 & 1.06 & 1.00 & 0.92 \\
\hline 3111099 & その他の事務用機械 & 1.25 & 1.06 & 1.00 & 0.92 & 1.38 & 1.06 & 1.00 & 0.92 \\
\hline 3311011 & ビデオ機器 & 3.58 & 2.51 & 1.00 & 0.60 & 3.62 & 2.43 & 1.00 & 0.60 \\
\hline 3311021 & 電気音響機器 & 1.51 & 1.22 & 1.00 & 0.95 & 1.41 & 1.18 & 1.00 & 0.96 \\
\hline 3311031 & ラジオ・テレビ受信機 & 2.27 & 1.67 & 1.00 & 0.55 & 2.47 & 1.83 & 1.00 & 0.48 \\
\hline 3321011 & 有線電気通信機器 & 1.45 & 1.26 & 1.00 & 0.96 & 1.44 & 1.22 & 1.00 & 0.95 \\
\hline 3321021 & 携帯電話機 & 5.08 & 1.90 & 1.00 & 0.72 & 5.22 & 1.90 & 1.00 & 0.72 \\
\hline 3321031 & 無線電気通信機器（除携帯電話機） & 1.28 & 1.13 & 1.00 & 0.88 & 1.21 & 1.05 & 1.00 & 0.97 \\
\hline 3331011 & パーソナルコンピューター & 7.01 & 4.28 & 1.00 & 0.66 & 9.40 & 5.18 & 1.00 & 0.66 \\
\hline 3331021 & 電子計算機本体（除パソコン） & 6.38 & 3.09 & 1.00 & 0.79 & 6.79 & 3.74 & 1.00 & 0.79 \\
\hline 3331031 & 電子計算機付属装置 & 1.83 & 1.54 & 1.00 & 0.88 & 1.80 & 1.47 & 1.00 & 0.87 \\
\hline 3411011 & 半導体素子 & 1.39 & 1.34 & 1.00 & 0.85 & 1.52 & 1.29 & 1.00 & 0.90 \\
\hline 3411021 & 集積回路 & 2.85 & 1.82 & 1.00 & 0.81 & 2.88 & 1.49 & 1.00 & 0.55 \\
\hline 3421011 & 電子管 & 2.33 & 1.65 & 1.00 & 0.73 & 1.76 & 1.31 & 1.00 & 0.73 \\
\hline 3421021 & 液晶素子 & 3.62 & 2.48 & 1.00 & 0.73 & 4.00 & 2.55 & 1.00 & 0.73 \\
\hline 3421031 & 磁気テープ・磁気ディスク & 2.60 & 1.87 & 1.00 & 0.83 & 2.57 & 1.87 & 1.00 & 0.58 \\
\hline 3421099 & その他の電子部品 & 1.51 & 1.28 & 1.00 & 0.92 & 1.48 & 1.27 & 1.00 & 0.94 \\
\hline \multicolumn{2}{|r|}{ 基本分類 } & \multicolumn{4}{|c|}{ 既存の産業連関表の国内生産額（2005 年価格） } & \multicolumn{4}{|c|}{ 新国内生産額（2005 年価格） } \\
\hline コード(行) & 部門名 & 1995 & 2000 & 2005 & 2008 & 1995 & 2000 & 2005 & 2008 \\
\hline 3111011 & 複写機 & $1,034,972$ & $1,352,527$ & 647,700 & 938,312 & $1,027,264$ & $1,297,458$ & 647,700 & 938,156 \\
\hline 3111099 & その他の事務用機械 & 809,621 & 985,992 & $1,128,834$ & $1,023,432$ & 736,692 & 986,030 & $1,128,834$ & $1,023,262$ \\
\hline 3311011 & ビデオ機器 & 351,690 & 577,677 & $1,535,804$ & $2,792,642$ & 347,902 & 595,540 & $1,535,804$ & $2,811,650$ \\
\hline 3311021 & 電気音響機器 & $1,448,732$ & $1,562,771$ & $1,185,641$ & 824,601 & $1,553,881$ & $1,617,114$ & $1,185,641$ & 815,770 \\
\hline 3311031 & ラジオ・テレビ受信機 & 416,788 & 387,162 & 742,929 & $1,901,310$ & 382,969 & 354,006 & 742,929 & $2,165,518$ \\
\hline 3321011 & 有線電気通信機器 & $1,265,026$ & $1,477,463$ & 686,538 & 611,260 & $1,271,083$ & $1,520,893$ & 686,538 & 616,558 \\
\hline 3321021 & 携带電話機 & 93,117 & 831,110 & $1,671,436$ & $1,767,922$ & 90,577 & 831,109 & $1,671,436$ & $1,768,069$ \\
\hline 3321031 & 無線電気通信機器（除携带電話機） & $1,135,210$ & $1,437,453$ & $1,114,938$ & $1,724,285$ & $1,198,078$ & $1,555,837$ & $1,114,938$ & $1,558,058$ \\
\hline 3331011 & パーソナルコンピューター & 270,455 & 574,558 & $1,296,644$ & $1,600,450$ & 201,639 & 474,803 & $1,296,644$ & $1,600,317$ \\
\hline 3331021 & 電子計算機本体（除パソコン） & 230,626 & 278,841 & 371,376 & 388,945 & 216,743 & 230,430 & 371,376 & 388,880 \\
\hline 3331031 & 電子計算機付属装置 & $2,469,089$ & $2,379,707$ & $2,013,424$ & $2,360,255$ & $2,519,002$ & $2,499,605$ & $2,013,424$ & $2,412,892$ \\
\hline 3411011 & 半導体素子 & 636,928 & 904,796 & $1,064,799$ & $1,296,368$ & 581,028 & 939,388 & $1,064,799$ & $1,233,285$ \\
\hline 3411021 & 集積回路 & $1,554,741$ & $2,769,824$ & $4,177,213$ & $5,381,045$ & $1,537,841$ & $3,389,595$ & $4,177,213$ & $7,938,070$ \\
\hline 3421011 & 電子管 & 343,450 & 271,030 & 306,912 & 497,995 & 455,117 & 339,743 & 306,912 & 497,995 \\
\hline 3421021 & 液晶素子 & 166,212 & 600,939 & $1,582,501$ & $2,468,245$ & 150,214 & 582,551 & $1,582,501$ & $2,468,245$ \\
\hline 3421031 & 磁気テープ・磁気ディスク & 183,170 & 257,604 & 410,947 & 402,721 & 185,308 & 257,604 & 410,947 & 577,127 \\
\hline 3421099 & その他の電子部品 & $4,763,296$ & $7,124,049$ & $8,669,384$ & $9,873,163$ & $4,876,902$ & $7,152,539$ & $8,669,384$ & $9,651,049$ \\
\hline
\end{tabular}


表 3 韓国及び日本のデフレーターによる国内生産額の変化（単位 : \%)

\begin{tabular}{|c|c|c|c|c|c|c|c|c|c|}
\hline \multicolumn{2}{|r|}{ 本稿の部門分類 } & \multicolumn{8}{|c|}{ 国内生産額の変化 } \\
\hline \multirow[b]{2}{*}{ コード } & \multirow[b]{2}{*}{ 部門名 } & \multicolumn{4}{|c|}{ 韓 国 } & \multicolumn{4}{|c|}{ 日 本 } \\
\hline & & 1995 & 2000 & 2005 & 2008 & 1995 & 2000 & 2005 & 2008 \\
\hline 8 & 電子管 & -42.5 & -17.1 & 0.0 & 10.6 & 32.5 & 25.4 & 0.0 & 0.0 \\
\hline 9 & 液晶素子 & 14.2 & -32.0 & 0.0 & 41.0 & -9.6 & -3.1 & 0.0 & 0.0 \\
\hline 10 & 半導体素子 & -19.5 & -15.0 & 0.0 & $14.1 \|$ & -8.8 & 3.8 & 0.0 & -4.9 \\
\hline 11 & 集積回路（IC） & -35.5 & -50.0 & 0.0 & 180.2 & -1.1 & 22.4 & 0.0 & 47.5 \\
\hline 12 & その他の電子部品 & -12.4 & -12.6 & 0.0 & 4.3 & 2.3 & 0.4 & 0.0 & -0.5 \\
\hline 14 & ラジオ・テレビ受信機 & -19.9 & 3.1 & 0.0 & 24.4 & -8.1 & -8.6 & 0.0 & 13.9 \\
\hline 15 & 音響機器 & -21.4 & -2.6 & 0.0 & $13.1 \|$ & 5.6 & 3.4 & 0.0 & 0.3 \\
\hline 16 & 有線通信機器 & -2.3 & -2.0 & 0.0 & 4.1 & 0.5 & 2.9 & 0.0 & 0.9 \\
\hline 17 & 無線通信機器·放送装備 & -63.2 & -50.1 & 0.0 & 53.6 & 4.9 & 5.2 & 0.0 & -4.8 \\
\hline 18 & コンピュータ・付属装置 & -47.2 & -41.1 & 0.0 & $44.1 \|$ & -1.1 & -0.9 & 0.0 & 1.2 \\
\hline \multirow[t]{2}{*}{19} & 事務用機械 & -6.4 & -6.7 & 0.0 & -8.2 & -4.4 & -2.4 & 0.0 & 0.0 \\
\hline & 全産業 & -0.6 & -1.3 & 0.0 & 6.4 & 0.0 & 0.1 & 0.0 & 0.3 \\
\hline
\end{tabular}

内生産額と比べてそれぞれ $0.0 \% ， 0.1 \%$, $0.3 \%$ 増加している。部門別にみると，国内生 産額の差が大きい部門は次のようである。韓国 の場合, 1995 年, 2000 年及び 2008 年の順の国 内生産額の増減を表すと,「8 電子管」は $-42.5 \%,-17.1 \%, 10.6 \%$,「11 集積回路 (IC)」は $-35.5 \%,-50.0 \%, 180.2 \%, 「 17$ 無線通信機器・放送装備」は $-63.2 \%$, $-50.1 \%, 53.6 \%, 「 18$ コンピューター・周辺 機器」は $-47.2 \% ，-41.1 \% ， 44.1 \%$ ある。 日本の場合, 1995 年, 2000 年及び 2008 年の順 の国内生産額の増減を表すと,「10半導体素 子」は $-8.8 \%, 3.8 \%,-4.9 \%, 「 11$ 集積回 路 (IC)」は $-1.1 \%, 22.4 \%, 47.5 \%, 「 14$ ラ ジオ・テレビ受信機」は $-8.1 \%,-8.6 \%$, 13.9\%である.

従って, 韓国は公表された既存の接続産業連 関表のパーシェ型デフレーターよりフィッシャ 一型デフレーターの価格低下が大きいことが明 らかになった。このことは, 既存の接続産業連 関表による ICT 製造部門における価格低下が 充分に反映されてないことを意味する。一方， 日本は, 既存の産業連関表のデフレーターとフ イッシャー型デフレーターの価格低下の差は大 きくないため全体の国内生産額の差もほとんど ない.このことは, 日本と比べて韓国の既存の 接続産業連関表の実質值のバイアスが大きい可 能性があることを意味する。つまり, 技術進歩
による質の上昇と伴う価格低下が起こることを 考慮すれば，ICT 製造部門においての技術進 歩が過小評価されていることを意味し，それに より接続産業連関表の実質值のバイアスが生じ ることを意味する。

\section{ICT 製造部門の生産性上昇に よるコスト削減効果}

\section{3-1 モデル式}

以上，固定基準年方式による既存の接続産業 連関表のデフレーター及び実質值のバイアス可 能性を検討した。特に韓国の ICT 製造部門に おける既存の接続産業連関表の実質值のバイア スは大きく, 技術進歩による価格低下が過小評 価されている可能性が大きいことがわかった。 このような ICT 製造部門における国内生産品 の価格低下の過少評価が経済全体及び他産業部 門にどのような影響をもたらすかを産業連関分 析の均衡価格モデルを用いてシミュレーション を行う。具体的には, 生産性 ${ }^{11)}$ 向上が日本と 韓国の ICT 製造部門において同様に生じるも のとして想定 ${ }^{12)} し$, 産業連関分析の均衡価格 モデルを用いて ICT 製造部門の生産性 $10 \%$ 上 昇が他産業部門に及ぼす直接・間接のコスト削 減効果のシミュレーションを行う。つまり，あ る特定産業の生産効率の上昇が経済全体の投 
入・産出関係を通じて, 直接・間接的に生産コ ス卜削減や価格低下の要因となり, 他産業の生 産効率上昇の要因となることを意味する。

まず，産業連関分析の均衡価格モデルは，国 内財価格 $\left(p_{d}\right)$ と輸入財価格 $\left(p_{m}\right)$ を区別し て行列形式で表すと次式である。

$$
\begin{aligned}
& P_{d}=A^{T}(I-\widehat{M}) p_{d}+A^{T} \widehat{M} p_{m}+v^{T} \\
& p_{d}=\left[I-A^{T}(I-\widehat{M})\right]^{-1}\left[A^{T} \widehat{M} p_{m}+v^{T}\right] \\
& p_{d}=\left[[I-(I-\widehat{M}) A]^{-1}\right]^{T}\left[A^{T} \widehat{M} p_{m}+v^{T}\right]
\end{aligned}
$$

ただし，Iは単位行列， $\widehat{M}$ は輸入係数の対角 行列, $A^{\mathrm{T}}$ は投入係数の転置行列, $v^{\mathrm{T}}$ は付加価 值率の転置した列ベクトルである。

そして，ある産業部門の生産性向上による他 産業に及ぼす直接・間接的コスト削減効果は, 他の生産要素の価格変化は一定という仮定で, TFP 変化分を外生変数として与えることによ って求めることができる. 従って, 国内財価格 への効果 $\left(\Delta p_{d}\right)$ は, 式 (3) を付加価值部門の 構成要素であるいわゆる本源的生産要素の間接 税, 労働コスト, 資本コストの変化分に分割 し, TFP 変化分を外生変数として与えて表す と次のようになる。

$$
\begin{aligned}
\Delta p_{d}= & {\left[[I-(I-\widehat{M}) A]^{-1}\right]^{T}\left[A^{T} \widehat{M} \Delta p_{m}+\Delta r\right.} \\
& \left.+\widehat{W}_{l} \Delta p_{l}+\widehat{W}_{k} \Delta p_{k}+\Delta t f p\right]
\end{aligned}
$$

ただし，rは間接税率の列べクトル， $p_{l}$ と $\widehat{W}_{l}$ は労働価格の列ベクトルと労働分配率の対角行 列， $p_{k}$ と $\widehat{W}_{k}$ は資本価格の列ベクトルと資本分 配率の対角行列, $\Delta t f p$ は特定産業部門の生産 性の変化分の列べクトルである。

分析結果は, ICT 製造部門の生産性 10\%上 昇による 65 部門 ${ }^{13)}$ へココト削減効果を 11 ブロック14)に集計を行う。ブロックへの集計 は，部門間波及効果を効率的に表すために，桜 本・新保・菅他 (1997）の三角化吕) の部門分 類を参考にして名目の国内生産額を用いてシェ アを取りディビジア型の集計方法を用いた。そ の際，韓国と日本の経済において重要性が高ま
っているサービス部門を知識サービス ${ }^{16)}$, 商 業サービス, 公共社会サービス, 個人・その他 サービスの 4 ブロックに集計する ${ }^{17)}$.

\section{3-2 分析結果}

ICT 製造部門の 11 部門の全てに対して生産 性上昇による他ブロックに与える影響について 実証分析する。そして，ICT 製造部門の中で も中間投入が大きい「11 集積回路 (IC)」の生 産性上昇による他ブロックに与える影響につい て実証分析する。その際に，ICT 製造部門に おいてフィッシャー型デフレーターを用いて作 成した接続産業連関表によるコスト削減効果は PFDIO-STA とし, 既存の公表されている接 続産業連関表によるコスト削減効果は IO-STA とする。

韓国の ICT 製造部門の生産性向上による影 響は次のようになる。

表 4 は, ICT 製造部門の 11 部門の生産性向 上による効果である。全産業の平均では, PFDIO-STA と IO-STA 両方とも 1995 年から 2008 年以降までのコスト削減効果はあるが, その効果は PFDIO-STA は減少しているのに 対してIO-STA は拡大している。また，コス 卜削減効果の大きさは, 2005 年以前は PFDIO-STA の方が IO-STA より約 1.04 倍大 きく, 2008 年以降は IO-STA の方が PFDIO-STA より約 1.02 倍大きい. そして, 自部門を除いた効果ではPFDIO-STA と IO-STA 両方とも激減しており, コスト削減 効果は自部門である ICT 製造部門に集中して いることがわかる。ブロック別の効果は, 自部 門が含まれる B と C ブロックの効果がもっと も大きくその次は $\mathrm{H}$ と $\mathrm{G}$ の順で大きい. そし て，B ブロックを除くとすべてのブロックの効 果は拡大している。特に $\mathrm{G}$ と $\mathrm{H}$ ブロックの効 果が大きく拡大しており，1995 年から 2008 年 以降までそれぞれ 4.7 倍, 2.6 倍の効果が拡大 している。

表 5 は, 集積回路（IC）の生産性向上によ る効果である。全産業の平均では, 
表 4 韓国の ICT 製造部門の生産性上昇によるコスト削減効果（単位：\%）

\begin{tabular}{|c|c|c|c|c|c|}
\hline \multicolumn{6}{|c|}{ 新接続産業連関表（PFDIO-STA） } \\
\hline 区分 & ブロック & $1995-2000$ & $2000-2005$ & $2005-2008$ & 2008 以降 \\
\hline & 建設業 & -0.001361 & -0.003344 & -0.006666 & -0.007388 \\
\hline & 機械工業 & -0.343817 & -0.322657 & -0.250012 & -0.228239 \\
\hline & ICT 関連部品 & -0.949955 & -1.006874 & -0.967923 & -0.957641 \\
\hline $\mathrm{D}$ & 金属製品 & -0.000665 & -0.000758 & -0.002196 & -0.002897 \\
\hline $\mathrm{E}$ & 製造業製品 & -0.000818 & -0.001045 & -0.001897 & -0.001805 \\
\hline & 素原材料・エネルギー製品 & -0.000441 & -0.000530 & -0.000989 & -0.001160 \\
\hline G & コンテンツ\&メディア & -0.002432 & -0.004400 & -0.009073 & -0.011429 \\
\hline & 知識サービス & -0.004665 & -0.005313 & -0.018471 & -0.012205 \\
\hline & 商業サービス & -0.001237 & -0.001596 & -0.003357 & -0.003324 \\
\hline $\mathrm{J}$ & 公共社会サービス & -0.002003 & -0.002415 & -0.003610 & -0.003124 \\
\hline & 個人・その他サービス & -0.001838 & -0.002068 & -0.002753 & -0.002817 \\
\hline & 平均 (PFDIO-STA) & -0.119021 & -0.122818 & -0.115177 & -0.112003 \\
\hline & 平均（自部門除, PFDIO-STA） & -0.002532 & -0.003248 & -0.006034 & -0.005684 \\
\hline & 平均 (IO-STA) & -0.114317 & -0.118643 & -0.115177 & -0.114437 \\
\hline & 平均（自部門除, IO-STA） & -0.002368 & -0.003090 & -0.006034 & -0.005889 \\
\hline
\end{tabular}

表 5 韓国の集積回路（IC）の生産性上昇によるコスト削減効果（単位：\%）

\begin{tabular}{|c|c|c|c|c|c|}
\hline \multicolumn{6}{|c|}{ 新接続産業連関表（PFDIO-STA） } \\
\hline 区分 & ブロック & $1995-2000$ & $2000-2005$ & $2005-2008$ & 2008 以降 \\
\hline A & 建設業 & -0.000025 & -0.000133 & -0.000148 & -0.000048 \\
\hline & 機械工業 & -0.006891 & -0.014079 & -0.003657 & -0.000859 \\
\hline & ICT 関連部品 & -0.508054 & -0.445755 & -0.323095 & -0.278464 \\
\hline & 金属製品 & -0.000014 & -0.000039 & -0.000041 & -0.000017 \\
\hline & 製造業製品 & -0.000020 & -0.000060 & -0.000049 & -0.000013 \\
\hline & 素原材料・エネルギー製品 & -0.000010 & -0.000027 & -0.000025 & -0.000008 \\
\hline & コンテンツ\&メディア & -0.000054 & -0.000223 & -0.000199 & -0.000064 \\
\hline $\mathrm{H}$ & 知識サービス & -0.000107 & -0.000231 & -0.000318 & -0.000070 \\
\hline $\mathrm{I}$ & 商業サービス & -0.000020 & -0.000067 & -0.000063 & -0.000019 \\
\hline $\mathrm{J}$ & 公共社会サービス & -0.000038 & -0.000108 & -0.000069 & -0.000019 \\
\hline & 個人・その他サービス & -0.000032 & -0.000082 & -0.000057 & -0.000017 \\
\hline & 平均 (PFDIO-STA) & -0.046842 & -0.041891 & -0.029793 & -0.025418 \\
\hline & 平均（自部門除, PFDIO-STA） & -0.000057 & -0.000177 & -0.000158 & -0.000046 \\
\hline & 平均 (IO-STA) & -0.046775 & -0.040602 & -0.029793 & -0.025499 \\
\hline & 平均（自部門除, IO-STA） & -0.000047 & -0.000152 & -0.000158 & -0.000051 \\
\hline
\end{tabular}

PFDIO-STA と IO-STA 両方とも 1995 年から 2008 年以降までのコスト削減効果はあるがそ の効果は減少している。ブロック別の効果は, 1995 年から 2008 年以降まで A，D，G ブロッ クを除くとすべてのブロックの効果は減少して いる.ブロック別の効果の大きさは，自部門が 含まれるCブロックの効果がもっとも大きい. また，無線通信機器・放送装備などの ICT 製 造部門への影響が大きいため B ブロックに影 響を与えている。そして，サービス部門への効 果は少ないものの G ブロックは 1995 年から
2008 年以前まで 3.7 倍の効果が拡大している.

日本の ICT 製造部門の生産性向上による影 響は次のようになる。

表 6 は，ICT 製造部門の 11 部門の生産性向 上による効果である。全産業の平均では, PFDIO-STA と IO-STA 両方とも 1995 年から 2008 年以降までのコスト削減効果はあるがそ の効果は減少している。また，コスト削減効果 の大きさは，1995 年から 2000 年までは PFDIO-STA の方が IO-STA より約 1.001 倍 大きく, 2000 年以降は IO-STA の方が 
表 6 日本の ICT 製造部門の生産性上昇によるコスト削減効果（単位：\%）

\begin{tabular}{|c|c|c|c|c|c|}
\hline \multicolumn{6}{|c|}{ 新接続産業連関表（PFDIO-STA） } \\
\hline 区分 & ブロック & $1995-2000$ & $2000-2005$ & $2005-2008$ & 2008 以降 \\
\hline & 建設業 & -0.002925 & -0.004029 & -0.004873 & -0.005829 \\
\hline & 機械工業 & -0.245510 & -0.207881 & -0.164021 & -0.157707 \\
\hline & ICT 関連部品 & -1.102207 & -1.099670 & -1.099953 & -1.077279 \\
\hline $\mathrm{D}$ & 金属製品 & -0.002506 & -0.003352 & -0.003921 & -0.004793 \\
\hline $\mathrm{E}$ & 製造業製品 & -0.002497 & -0.004091 & -0.006008 & -0.007165 \\
\hline & 素原材料・エネルギー製品 & -0.001838 & -0.002350 & -0.003333 & -0.003927 \\
\hline & コンテンツ\&メディア & -0.003233 & -0.004428 & -0.005437 & -0.005004 \\
\hline & 知識サービス & -0.001839 & -0.002601 & -0.003516 & -0.003786 \\
\hline I & 商業サービス & -0.001419 & -0.001783 & -0.002839 & -0.003601 \\
\hline $\mathrm{J}$ & 公共社会サービス & -0.002733 & -0.003625 & -0.004220 & -0.005070 \\
\hline & 個人・その他サービス & -0.005326 & -0.007946 & -0.010744 & -0.014569 \\
\hline \multicolumn{2}{|r|}{ 平均 $(\mathrm{PFDIO}-\mathrm{STA})$} & -0.124730 & -0.121978 & -0.118988 & -0.117157 \\
\hline \multicolumn{2}{|r|}{ 平均 (自部門除, PFDIO-STA) } & -0.004079 & -0.005648 & -0.007417 & -0.008631 \\
\hline \multicolumn{2}{|r|}{ 平均 (IO-STA) } & -0.124626 & -0.123471 & -0.118988 & -0.118732 \\
\hline \multicolumn{2}{|r|}{ 平均（自部門除，IO-STA） } & -0.004088 & -0.005690 & -0.007417 & -0.008701 \\
\hline
\end{tabular}

表 7 日本の集積回路（IC）の生産性上昇によるコスト削減効果（単位：\%）

\begin{tabular}{|c|c|c|c|c|c|}
\hline \multicolumn{6}{|c|}{ 新接続産業連関表（PFDIO-STA） } \\
\hline 区分 & ブロック & $1995-2000$ & $2000-2005$ & $2005-2008$ & 2008 以降 \\
\hline A & 建設業 & -0.000180 & -0.000291 & -0.000399 & -0.000419 \\
\hline & 機械工業 & -0.011490 & -0.013172 & -0.011036 & -0.009823 \\
\hline & ICT 関連部品 & -0.256638 & -0.248440 & -0.243153 & -0.238971 \\
\hline & 金属製品 & -0.000074 & -0.000159 & -0.000250 & -0.000282 \\
\hline & 製造業製品 & -0.000389 & -0.000732 & -0.000889 & -0.000924 \\
\hline & 素原材料・エネルギー製品 & -0.000084 & -0.000134 & -0.000235 & -0.000243 \\
\hline & コンテンツ\&メディア & -0.000069 & -0.000140 & -0.000251 & -0.000247 \\
\hline & 知識サービス & -0.000066 & -0.000122 & -0.000201 & -0.000212 \\
\hline $\mathrm{I}$ & 商業サービス & -0.000069 & -0.000109 & -0.000201 & -0.000229 \\
\hline & 公共社会サービス & -0.000143 & -0.000174 & -0.000287 & -0.000331 \\
\hline & 個人・その他サービス & -0.000230 & -0.000433 & -0.000756 & -0.000886 \\
\hline & 平均 (PFDIO-STA) & -0.024494 & -0.023991 & -0.023423 & -0.022960 \\
\hline & 平均（自部門除, PFDIO-STA） & -0.000335 & -0.000600 & -0.000843 & -0.000871 \\
\hline & 平均 (IO-STA) & -0.024558 & -0.023994 & -0.023423 & -0.022988 \\
\hline & 平均（自部門除, IO-STA） & -0.000337 & -0.000600 & -0.000843 & -0.000873 \\
\hline
\end{tabular}

PFDIO-STA より約 1.01 倍大きい. そして, 自部門を除いた効果はPFDIO-STA と IO-STA 両方とも 1995 年から 2000 年まで約 30.6 倍, 2000 年から 2005 年まで約 21.6 倍, 2005 年から 2008 年まで 16.0 倍，そして 2008 年以降約 13.6 倍も激減しているが，その程度 は韓国のそれぞれの同様な期間中の 49.4 倍, 41.6 倍, 21.1 倍, 22.2 倍に比べると小さい. ブロック別の効果は, 自部門が含まれる B と $\mathrm{C}$ ブロックの効果がもっとも大きくその次は $\mathrm{K}$ と $\mathrm{E}$ の順で大きい. そして， B と C ブロック
を除くとすべてのブロックの効果は拡大してい る。特に K ブロックの効果が大きく拡大して おり，1995 年から 2008 年以降まで 2.7 倍の効 果が拡大している。

表 7 は, 集積回路（IC）の生産性向上によ る効果である。

全産業の平均では, PFDIO-STA と IOSTA 両方とも 1995 年から 2008 年以降までの コスト削減効果はあるがその効果は減少してい る。ブロック別の効果は，1995 年から 2008 年 以降までほとんどのブロックの効果が減少して 
図 2 韓国と日本の ICT 製造部門の生産性上昇によるコスト削減効果（自部門除）

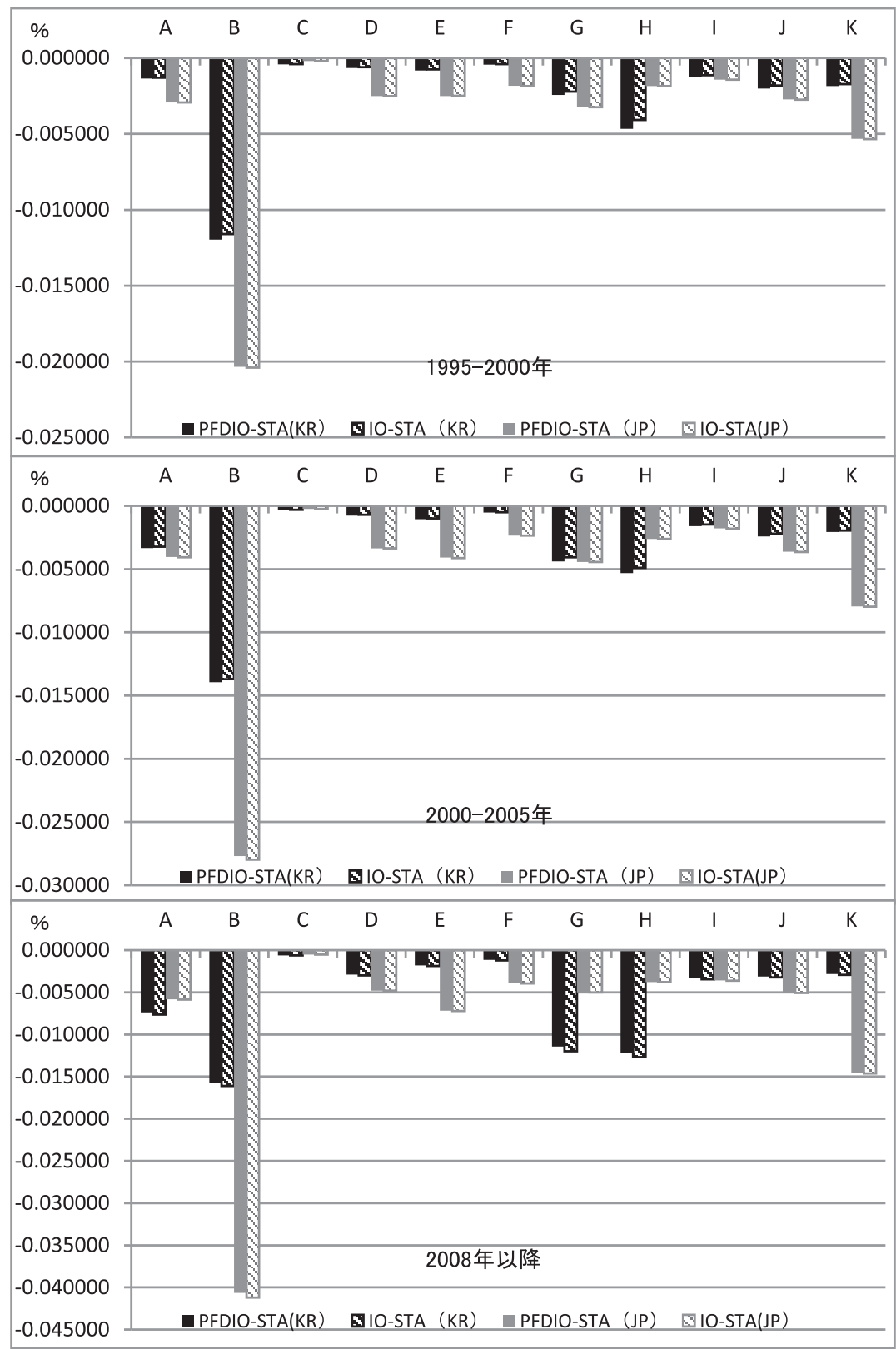

いる韓国と異なって，日本は B，C ブロックを 除くとすべてのブロックの効果は拡大してい る。ブロック別の効果の大きさは，自部門が含 まれるCブロックの効果がもっとも大きい。 また，電気機械，自動車部門などの非 ICT 製 造部門への影響が大きいため B ブロックに影 響を与えている。そして，サービス部門への効
果は少ないものの K ブロックは 1995 年から 2008 年以降まで 3.9 倍の効果が拡大している。

図 2 は, 韓国と日本の 1995 年から 2008 年以 降までの ICT 製造部門の 11 部門の生産性向上 による効果を PFDIO-STA と IO-STA のブロ ック別に比較したものである ${ }^{18)}$ 。そして，他 ブロックへの影響を明らかにするため，自部門 
（ICT 製造部門）への影響は除いている。

まず，韓国の場合，効果が大きいブロック は，B， H， Gの順となっている。これらのブ ロックの効果を全産業の平均值でみると, 1995 年から 2000 年までは IO-STA (KR) は -0.002368\%であったのに対して PFDIOSTA（KR）の効果は $-0.002532 \%$ と後者が前 者の約 1.07 倍の大きなコスト削減効果がある。 2000 年から 2005 年までは IO-STA（KR）は -0.003090\%であったのに対して PFDIOSTA（KR）の効果は $-0.003248 \%$ と後者が前 者の約 1.05 倍の大きなコスト削減効果がある. それに対して，20008 年以降は IO-STA（KR） は $-0.005889 \%$ であったの対して PFDIO-STA（KR）の効果は $-0.005684 \%$ と 前者が後者の約 1.04 倍の大きなコスト削減効 果がある。

日本の場合, 効果が大きいブロックは, B と $\mathrm{K}$ の順である。これらのブロックの効果を全 産業の平均值でみると，1995 年から 2008 年以 降までIO-STA（JP）と PFDIO-STA（JP） の効果の大きさは韓国と異なってほとんど変わ らない。 そして，日本は $\mathrm{A}$ と $\mathrm{G}$ の一部の期間 と C, H のブロックを除くとすべてのブロック において韓国よりコスト削減効果が大きい。こ のことは，表 4 と表 6 の両国の自部門を含む場 合のコスト削減効果を考慮すれば19), 生産性 向上へのコスト削減効果は, 日本と比べて韓国 の場合 ICT 製造部門（自部門）に集中してい ることが分かる。また, 韓国の場合, H ブロ ックは 1995 年から 2008 年以降まで日本より効 果が大きく拡大している。そして，Gブロック は 2008 年以前は日本の効果が大きかったのに 対して, 2008 年以降は韓国の効果が大きく拡 大し日本の効果を上回っている.

\section{4. おわりに}

本稿では, 1995 年から 2008 年までの日本と 韓国の ICT 製造部門において，既存の公表さ れた接続産業連関表の固定基準年方式によるバ
イアスを取り除くためにフィッシャー型のデフ レーターによる実質化を行った。また ICT 製 造部門の生産性向上が, 産業間の相互依存関係 を通じて，他産業部門の生産性に与える効果の 測定を行った。

その結果, ICT 製造部門の価格低下の拡大 によって，日本と韓国の他産業部門及び経済全 体にコスト削減効果あるいは生産性向上の影響 を及ぼすことが確認できた。特に，韓国の場合 ICT 製造部門における既存の接続産業連関表 の実質值のバイアスが大きく，技術進歩に伴う 価格低下が過小評価されている可能性が大きい ことがわかった。また，公表されている接続産 業連関表の実質值のバイアスによってコスト削 減効果が過少または過大評価されていることが わかった。そして, ICT 製造部門の生産性向 上によるコスト削減効果は, 韓国の場合, 日本 より ICT 製造部門に集中しており，他産業部 門へコスト削減効果は日本より少ないことが分 かった。従って, 韓国においては, 非 ICT 部 門及び成長部門であるコンテンツ＆メディアと 知識サービスのブロックへの ICT 活用を高め ることによって経済全体への生産性向上につな がると考えられる。それに対して，日本の場合 は，非 ICT 製造部門への影響が大きかった。 ただし，韓国と異なって成長部門として注目さ れている知識サービスやコンテンツ＆メデイア のブロックは ICT 活用が少ないことが原因で コスト削減効果の影響は低かったのに対して個 人・その他サービスへの効果は大きかった。

本稿では, 情報通信機器の生産性向上が中間 財の投入産出関係を通じて他産業部門の生産性 に与える効果を検討した。しかし，情報通信機 器は資本財として各産業部門の生産活動に大き く寄与するはずである。 そのため，今後の課題 として，資本財を内生化した動学モデルによる 方法でより中長期的な観点で分析を行うべきで ある。

\section{[謝辞]}

本稿は, 作成にあたり桜本光教授（慶應義塾大学商 
学部)に多くの助言をいただきました。記して謝意を 表したい. また, 本稿は, 第 39 回商学研究科研究報告 会の際に早見均教授 (慶應義塾大学商学部), 新保一成 教授 (慶應義塾大学商学部) に, 情報通信産業や分析 方法について極めて重要なコメントをいただきました。 今回の論文はその際のコメントの一部を反映した論文 である。まだ解決されてない課題に関しては引き続き 研究に反映し継続していきたい.

\section{[資料・データ]}

総務省（2009）「平成 17 年産業連関表一総合解説偏」

総務省（2009）「平成 17 年産業連関表一計数編 (1)」

総務省（2004）「平成 12 年産業連関表一計数編 (1)」

総務省（1999）「平成 7 年産業連関表一計数編 (1)」

総務省（2010）「平成 7-12-17 年接続産業連関表」

経済産業省 http://www.meti.go.jp/

日本銀行 http://www. boj.or.jp/

韓国銀行（2010）「2008 年産業連関表」

韓国銀行（2008）「2005 年産業連関表」

韓国銀行（2003）「2000 年産業連関表」

韓国銀行（1998）「1995 年産業連関表」

韓国銀行（2009）「1995-2000-2005 年接続不変産業連関 表」

韓国銀行 http://ecos.bok.or.kr/

国家統計ポータルサイト http://kostat.go.kr/

OECD (2006) Innovation and Knowledge-Intensive Service Activities, Paris.

\section{〔注]}

1）日本では同様の言葉として IT (Information Technology：情報技術）の方が普及しているが, OECD など国際的には ICT の方が通りがよい.そ のため本稿では ICT とする。 ただし, 先行論文で IT という言葉を使った場合, 先行論文の説明を行 う際は本稿の中でもそれをそのまま使う。

2）本稿の ICT 製造部門の定義は OECD (2007), OECD（2009）による定義を参考に作成した。

3） 1995-2000-2005 年接続産業連関表と 2008 年延 長表を用いて作成する。

4）日本と韓国の接続産業連関表のインフレーター は, 単価法, 物価指数法, 数量指数法, 投入コス ト法の 4 つの方式により作成している. 日本の場 合, 総務省「平成 7-12-17 年接続産業連関表一総 合解説編」の pp204-230 にインフレーター作成に 関して詳しい説明がされており, ICT 製造部門に 対する国内生産品インフレーターは, パーシェ型 の物価指数法により作成している。パーシェ型の 物価指数法とは, 品質変化が著しい品目に対して 用いられ方法であり, 細品目の国内生産額をウェ
イトとして物価倍率を加重して作成する方法であ る.そして，デフレーターとインフレーターは逆 数関係の概念である. なお, 本稿では, 物価指数 法を物価指数方法とする.

5）月次指数を暦年に換算すると 2005 年が 1 になら ないので. 2005 年の平均が 1 になるように調整し た。また，参考指数として連鎖方式による企業物 価指数を公表しているが, 本稿では, 固定ラスパ イレスの企業物価指数を利用する.

6） 1995 年基準は, 1995 年から 2002 年まで, 2000 年基準は 1999 年から 2007 年まで，2005 年基準は 2004 年から 2011 年までの国内企業物価指数を用 いて 1995 年から 2011 年までの接続物価指数を作 成した。

7）「生産動態統計調査」は商品を単位とする統計で あるのに対し,「工業統計調査」は事業所を単位と する統計で，事業所単位を商品組換した商品単位 の統計を用いている。そして，どの統計を利用す るかによって，国内生産額の推計は大幅に異なる. そのため, 両方の統計資料を参考にして推計を行 う.

8）「生産動態統計調査」に品目が存在しないか品目 が不明な場合，また，2005 年の「生産動態統計調 査」と「部門別品目別国内生産額表」の生産額が 大きく異なる場合は，「工業統計調査」を用いて推 計を行う。

9） ICT 製造部門は, 電子管, 液晶素子, 半導体素 子, 集積回路 (IC), その他の電子部品, ラジオ・ テレビ受信機, 音響機器, 有線通信機器, 無線通 信機器・放送装備, コンピューター・付属装置, 事務用機械の 11 部門である。

10) 国内生産額の変化 $=($ 新国内生産額 - 既存の産 業連関表の国内生産額）/既存の産業連関表の国内 生産額 $\times 100$

11）本稿での生産性は, 生産投入要素として労働, 資本, 中間財を含む全要素生産性（Total Factor Productivity: TFP) を意味する。

12）実際の TFP の計測值は残差という形で得られ る事後的な情報であるため, その計測值をそのま ま TFP 変化と解析して分析することはミスリーデ イングな結果を招きやすいので，本稿では，該当 部門に対して生産性上昇 $10 \%$ があるとする。

13）仮設部門である「事務用品」と「分類不明」は 除く.

14）付表 1 を参考.

15）桜本・新保・菅他（1997）によると，三角化に よる再配列を行うと，上部に位置する加工度が高 い産業 (最終財) は中間財として投入されること が少なく，逆に下部に位置する中間素材は多くの 部門に中間財として投入される。つまり，ある部 
付表 1 本稿のブロック分類と部門名

\begin{tabular}{|c|c|c|}
\hline & ブロック & 部門名 \\
\hline A & 建設業 & \begin{tabular}{|l|l}
46 & 建築 \\
47 & 土及び特殊建設 \\
22 & 通信施設建設 \\
\end{tabular} \\
\hline B & 機械工業 & \begin{tabular}{|l|l}
41 & 自動車 \\
42 & 船舶 \\
43 & その他の輸送機械 \\
37 & 一般機械 \\
38 & 電気機械 \\
39 & 医療用機械器具 \\
40 & 精密機械 \\
14 & ラジオ・テレビ受信機 \\
15 & 音響機器 \\
16 & 有線通信機器 \\
17 & 無線通信機器・放送装備 \\
18 & コンピュータ・付属装直 \\
19 & 事務用機械 \\
\end{tabular} \\
\hline $\mathrm{C}$ & ICT 関連部品 & \begin{tabular}{|c|c|}
8 & 電子管 \\
9 & 液晶素子 \\
10 & 半導体素子 \\
11 & 集積回路 (IC) \\
12 & その他の電子部品 \\
13 & 電線・ケーブル \\
\end{tabular} \\
\hline D & 金属製品 & \begin{tabular}{|l|l|}
34 & 鉄鋼 \\
35 & 非鉄金属 \\
36 & 金属製品 \\
\end{tabular} \\
\hline $\mathrm{E}$ & 製造業製品 & \begin{tabular}{|l|l}
28 & 飲・食料品 \\
29 & 瀻維・皮製品 \\
30 & パルプ・紙・木製品 \\
32 & 化学製品 \\
33 & 窐業・土石製品 \\
44 & その他の製造工業製品 \\
\end{tabular} \\
\hline F & $\begin{array}{c}\text { 素原材料· } \\
\text { エネルギー製品 }\end{array}$ & \begin{tabular}{|l|l|}
26 & 農林水产業 \\
27 & 鉱山品 \\
31 & 石油・石炭製品 \\
45 & 電力・ガス・熱供給・水道 \\
\end{tabular} \\
\hline $\mathrm{G}$ & $\begin{array}{l}\text { コンテンツ } \\
\quad \& \\
\text { メディア }\end{array}$ & \begin{tabular}{|l|l|}
1 & 印刷・製版・製本 \\
2 & 情報記録物・複製 \\
3 & 新聞 \\
4 & 出版 \\
5 & 映画・音楽・その他芸術 \\
6 & 放送 \\
7 & 広告 \\
\end{tabular} \\
\hline $\mathrm{H}$ & 知識サービス & \begin{tabular}{|l|l}
20 & 電気通信 \\
21 & ソフトウエア開発供給・コンピュータ関連サービス \\
23 & 研究機関 (国・公立) \\
24 & 研究機関 (非営利及び産業) \\
25 & 企業内研究開発 \\
51 & 金融・保険 \\
53 & 対事業所サービス \\
\end{tabular} \\
\hline I & 商業サービス & \begin{tabular}{|l|l|}
48 & 商業 \\
49 & 運輸 \\
\end{tabular} \\
\hline $\mathrm{J}$ & $\begin{array}{c}\text { 公共 } \\
\text { 社会サービス }\end{array}$ & \begin{tabular}{|l|ll}
55 & 公務 \\
56 & 教育機関 (国公立) \\
57 & 教育機関 (非営利) \\
58 & 教育機関 (産業) \\
59 & 医療 \\
60 & 社会保障 \\
61 & 衛生サービス
\end{tabular} \\
\hline K & $\begin{array}{c}\text { 個人・ } \\
\text { その他サービス }\end{array}$ & \begin{tabular}{|l|l}
50 & 郵便・信書便 \\
52 & 不動産 \\
54 & 物品賃貸業 \\
62 & 娛楽サービス \\
63 & 飲食店・宿泊 \\
64 & 修理サービス \\
65 & 対個人サービス
\end{tabular} \\
\hline
\end{tabular}

門の生産性向上による部門波及効果は一方向であ り, 加工度が高い部門の生産性向上は加工度の低 い部門に影響を与えないが，逆に加工度が低い部 門の生産性向上は加工度の高い部門に影響を与え ることになる。

16） OECD（2006）によると，知識基盤部門とは， 知識，情報，高技術集約部門やそれらを多く必要 とされるセクターと定義されている。

17）以降の結果表では， 5 年階差と 3 年階差が含ま れているが，変化率の調整は行っていない.

18）韓国は KR，日本は JP とする。

19）表 4 と表 6 を見ると，全産業の平均（PFDIOSTA）は日本が韓国より 0.99 倍から 1.05 倍効果 が大きい。一方，自部門の除く全産業の平均（自 部門除，PFDIO-STA）は日本が韓国より 1.23 倍 から 1.74 倍効果が大きい。つまり，韓国が日本よ り ICT 製造部門に対するコスト削減効果が集中し ていることが分かる.

\section{参考文献}

李建雨（1997）「韓国産業の成長と構造変化：台湾との 比較に基づいた重化学工業化政策の再評価」博士学 位論文，慶應義塾大学（商学)。

菅宜紀（1995）「接続産業連関表の作成」『産業連関一 イノベーション\& I-O テクニークー」』環太平洋産業 連関分析学会，第 6 巻第 1 号, pp.46-53.

桜本光・新保一成・菅幹雄 - 貝沼直之 ·平下克己 - 浦 島良日留・二宗仁史（1997）「わが国経済成長と技術 特性」『経済分析』第 149 号，経済企画庁経済研究 所, pp.1-99.

篠嵉彰彦・山本悠介（2010）「IT 関連産業の経済波及 効果一産業連関表による 1990 年から 2005 年までの 分析」『経済学研究』第 76 巻第 4 号 pp.67-82.

中村慎一郎 (2000) 『Excel で学ぶ産業連関分析』エコ ノミスト社。

キム・ジョンゥン，パク・ソンゥック，キム・ミンシ キ，ジョン・ヒョンジュン (2010)「産業別 IT 融合 統計構築法案 (韓国語)」『政策研究 10-33』, 情報通 信政策研究院.

シン・ショクハ（2008）「情報通信技術の発展と産業別 総要素生産性（韓国語）」『政策研究シリーズ 200810』, 韓国開発研究院.

Jorgenson, Dale W. and Khuong Vu. (2005) "Information Technology and the World Economy", Scandinavian Journal of Economics, Vol.107, No.4, pp. 631-650.

OECD (2007) "Information Economy Sector Definitions Based on the International Standard Industry Classification (ISIC 4)", Working Party on Indicators for the Information Society, DSTI/ICCP/IIS (2006) 2/ 
FINAL, Paris, pp.1-16.

OECD (2009) Guide to Measuring the Information Soci- ety 2009, Paris, pp.31-39. 